Journal of Humanities and Social Sciences Studies (JHSSS)

ISSN: 2663-7197

DOI: $10.32996 /$ jhsss

Journal Homepage: www.al-kindipublisher.com/index.php/jhsss

\title{
Book Review: The Golden Maze: A biography of Prague
}

\section{William W. Bostock}

University Associate, School of Social Sciences, University of Tasmania, Australia

$\square$ Corresponding Author: William W. Bostock, E-mail: WilliamBostock@utas.edu.au

\section{ARTICLE INFORMATION ABSTRACT}

Received: 28 September 2021

Accepted: 20 October 2021

Published: 31 October 2021

DOI: 10.32996/jhsss.2021.3.10.4x

\section{KEYWORDS}

The Golden Maze: A biography of

Prague, Richard Fidler
The review is of the book The Golden Maze, A Biography of Prague by Richard Fidler (2020) which analyses the history of Prague and the Czech people for whom it has been capital and cultural centre for over 1000 years. Its history has been turbulent, surrounded by its powerful forces. Despite this, it has survived German occupation during World War II, and then Soviet control until 1989. In 1993, without a referendum, the country of Czechoslovakia was peacefully split between the Czech and the Slovak people. The book makes a positive contribution to understanding this complex process.

\section{Book Review: The Golden Maze: A biography of Prague}

\author{
William W. Bostock \\ University of Tasmania, Australia
}

The Golden Maze: A biography of Prague

By Richard Fidler

Sydney: Harper Collins, for ABC Books, 2020

580 p; ISBN: 9780733335266 (Hardback), 9781460706923 (ebook)

Reviewed by William W. Bostock

University of Tasmania, Australia

Over the centuries, countless communities have socialized their members into a distinct cultural configuration necessary for survival, often when confronted with the stark choice of adapting or going under. The Golden Maze presents in this light the story of Prague and the Czech people.

In the asteroid belt beyond Mars lies the asteroid 264 Libussa, named after the witch queen of Bohemia, who is said to have founded Prague over 1000 years ago. Prague Castle was built in the late Middle Ages, and since then, the city of Prague has served as the capital or provincial capital of a variety of kingdoms, republics and other political forms. After 1000 years in the Holy Roman Empire, Bohemia came under the rule of the Habsburgs, and after the First World War, achieved independence with their Slovak cousins as Czechoslovakia. The first Czechoslovak Republic brought together the Czech lands of Bohemia and Moravia in the west, with Slovakia and part of Ruthenia in the east, and its 20 years of existence was seen as a golden age of democracy, economic development and cultural expression. This came to an end with Nazi occupation in 1939 when Czech lands became the Protectorate of Bohemia and Moravia, while that part with a Germanophone population, Sudetenland, was incorporated into the Third Reich.

Copyright: (C) 2021 the Author(s). This article is an open access article distributed under the terms and conditions of the Creative Commons Attribution (CC-BY) 4.0 license (https://creativecommons.org/licenses/by/4.0/). Published by Al-Kindi Centre for Research and Development, London, United Kingdom. 
The extremely stressful years of Nazi Occupation were marked by a single event, the assassination in 1942 of Reichsprotektor Reinhard Heydrich, by Czech agents assisted by the British who were, in turn, responding to pressure from Benes, the leader of the Czech government in exile. Nazi response to the assassination was, as predicted by its organizers, profound and far-reaching, leading to the deaths of an estimated 10,000 Czechs and the destruction of the village of Lidice.

In the closing stages of World War II, Churchill, Roosevelt and Stalin agreed that Czechoslovakia would be under the control of the USSR, a situation that lasted from 1945 to 1989. This period was one of continuing unrest and sporadic repression, particularly in the Prague Spring of 1968 when the Czech government under the leadership of Alexander Dubcek sought greater autonomy, democratization and rehabilitation of the victims of Stalinism. With the threat of 200,000 Soviet and Warsaw Pact troops ready to invade, the Czech government capitulated. As Dubcek said at the time, "I have always loved Russia. I have devoted my entire life to cooperating with the Soviet Union, and this is what they have done to me." (p. 391).

1989 saw the popularly supported playwright Vaclav Havel elected to the presidency, going from prison to Prague Castle in the process called the Velvet Revolution. Within Czechoslovakia, nationalist proponents called for and achieved a peaceful separation between Czechs and Slovaks. On January 1, 1993, without the holding of a referendum, this was formalized, in a process described by Havel as the greatest failure of his presidency. In 2004, the Czech Republic joined the European Union.

In his book of over 500 pages, Richard Fidler, a well-known and highly respected writer and media figure in Australia, has presented a description and analysis of how a distinct ethnic group, located between powerful neighbours at the crossroads of Europe, has managed to survive and prosper. This has been the story of an intense interaction between political culture and socialization, as shown in the biographies of the main individual actors. From Thomas Masaryk (1850-1937), the statesman, to his son Jan Masaryk (1886-1948), through Edvard Benes (1884-1948), leading his government in exile through the shock and devastation over British and French acceptance of Nazi takeover, to Alexander Dubcek (1921-1992), and finally to Vaclav Havel (1936-2011). The impact of cultural expression from figures such as the composer Dvorak in music and Franz Kafka in literature is also covered. In short, Fidler has provided a valuable addition to the understanding of an important and enduring Central European nation. 